\title{
PROPHYLACTIC, ANTI-PAEDOPHILE HYMN-WRITING IN COLONIAL INDIA: AN INTRODUCTION TO AMY CARMICHAEL (1867-1951) AND HER MISSIONARY WRITINGS
}

\section{Introduction}

Perhaps because she was a missionary and her writings could be regarded as having the distasteful taint of imperial proselytizing, the prolific devotional works of Amy Carmichael are virtually unknown in English literary studies. ${ }^{1}$ This is probably also related to the fact that, until recently, Michael Wheeler's statement that, for modern critics, 'religion is something of an embarrassment' held true. ${ }^{2}$ However, during the past decade there has been a growing movement within English studies to recognize the place of religion in literature, particularly the impact of confessional positions on the inscription of cultural experience. Even within women's studies, where the dominant belief for early feminists was that Christianity was a patriarchal system which oppressed women, the history of women and Christianity has become a more acceptable field of study. As Jacqueline De Vries observes in a recent assessment of feminist responses to Christianity:

Over the last decade and a half, [...] feminist analysis has shifted away from paradigms emphasizing victimization and oppression above all else, opening up possibilities for less reactionary, more nuanced assessments of religion and its relationship to women's roles, self-definitions, and emancipation. ${ }^{3}$

At the same time, missiology is being recognized as a field that can offer critical insight into areas as varied as anthropology, travel writing, theology, literature, and history. It is within this context that I introduce Carmichael's distinctive missionary writings: in particular, her verse written in response to her work with the Dohnavur Fellowship, an organization which she established in southern India for the protection of vulnerable children.

This article develops out of my Ph.D. thesis 'The Ministry of Song: Unmarried British Women's Hymn Writing, 1760-1936' (Durham University, 2007), and I thank the AHRC for funding the research undertaken for the degree. The Dohnavur Fellowship and CLC Publications have graciously granted permission to quote from Amy Carmichael's verse. Thanks also to Alison Shell for her comments on an earlier version.

' She is sometimes also known as Amy Wilson-Carmichael. This was her nom de plume until 1922, and signalled her special connection with Robert Wilson (1825-1905), a Quaker industrialist who sponsored the Evangelical Keswick Conventions in the final decades of the nineteenth century, and to whom she became like a surrogate daughter after their meeting in 1887.

${ }^{2}$ Michael Wheeler, Heaven, Hell and the Victorians (Cambridge: Cambridge University Press, 1994), p. 2.

Jacqueline De Vries, 'Rediscovering Christianity after the Postmodern Turn', Feminist Studies, 31 (2005) 235-55 (p. 137).

Modem Lenguage Review, 104 (2009), 353-74

- Modern Humanities Research Association 2000 
Amy Beatrice Carmichael was born on 16 December 1867 in Millisle, a coastal village in County Down, Northern Ireland. She was the eldest of the seven children of David Carmichael, the prosperous owner of several local flour mills, and his wife, Catherine Jane Filson Carmichael. The Carmichaels had originated from Ayrshire, Scotland, and remained devout Presbyterians. After her father's death in April 1885, Carmichael was drawn increasingly to Christian social work among the poor, first in Belfast and then in Manchester. By the late 188 os her religious views were deeply influenced by the theology of the Keswick Convention, a leading organization promoting the Evangeli$\mathrm{cal}$ Holiness Movement in Britain during the final decades of the nineteenth century. As D. W. Bebbington explains:

From the 1870 s onwards Evangelicalism was deeply influenced by a new movement. Advocates of holiness teaching urged that Christians should aim for a second decisive experience beyond conversion. Afterwards they would live on a more elevated plane. [...]

The new style of devotion laid stress on the 'rest of faith'. With the struggle over, trust brought calm to the soul. ${ }^{4}$

With this call to holiness, Carmichael desired a life of service to God, and in January 1892 she identified a calling to overseas mission. After some difficulty in deciding where to serve, she finally reached India (via service in Japan and Ceylon) as a missionary of the Church of England Zenana Missionary Society. ${ }^{5}$ She remained in India from her arrival on 9 November 1895 until her death over fifty years later.

\section{The Protection of Children}

The work for which Carmichael has become best known-'a legend in evangelical circles, perhaps more than any other woman missionary' ${ }^{6}$-is the establishment of the Dohnavur Fellowship. The work started in the Tinnevelly (now Tirunelveli) district of southern India, and was concerned with the plight of vulnerable children: child widows, orphans, and, most notably, devadasis,

4 D. W. Bebbington, Evangelicalism in Modern Britain: A History from the 1730s to 1980 (London and New York: Routledge, 1989), p. 151.

5 The Church of England Zenana Missionary Society (hereafter CEZMS) was founded in 1880 when it separated from the interdenominational Indian Female Normal School Society. Its original aim was for British women missionaries to evangelize Indian women by means of zenana visits, teacher-training schools, medical missions, and schools for Muslim and Hindu girls. Their overseas mission work spread to China in 1884, Japan in 1886, and Ceylon in 1889. Despite not being an Anglican, Carmichael was accepted by the Society because of her strong connection with the largely Anglican Keswick Convention-especially with Robert Wilson, as explained in note 1 above.

- Ruth A. Tucker, 'Biography as Missiology', Missiology: An International Review, 27 (1999), 429-40 (p. 431). Later on the same page Tucker asserts that 'She was in many ways the Protestant version of Mother Teresa'. Carmichael was awarded the Kaiser-I-Hind medal for distinguished service to India in 1919. 
young girls who were given in marriage to the temple deity in some parts of India. The devadasi system, an ancient Hindu custom whereby girls were trained as temple dancers and musicians for the performance of religious rites, had deteriorated to a kind of prostitution, whereby young girls were open to sexual exploitation. ${ }^{7}$ Much of the missionary community had been largely unaware of this custom until Carmichael started to publicize her experiences with children 'rescued' from such circumstances.

She first revealed the situation in Things as They Are (1903), in which she recalled how, one evening, she met two unfamiliar men accompanying a local child. She records her shock at discovering that the child was being taken to the temple to be 'married' to the god. After witnessing the wedding celebrations, and realizing the potential (sexual) implications of the marriage, she wrote: 'We are told not to modify things, not to write too vividly, never to harrow sensitive hearts. Friends, we cannot modify truth, we cannot write half vividly enough; and as for harrowing hearts, oh that we could do it!' ${ }^{18}$ On the opposite page she included a plate, a frightening photograph of an ominous-looking temple high priest-one whom she understood as having rights over the child. She closed the chapter with the following provocative thoughts:

I knew something of the man. His life is simply unthinkable. [. . . Look at him till you feel as if you have seen him. [...]

Now, put a flower in his hand-a human flower this time. Now put beside him, if you can, a little girl-your own little girl-and leave her there-yes, leave her there in his hand. ${ }^{9}$

By challenging her readers emotionally, Carmichael was attempting to raise awareness and enlist help for the children. She continued with this undertaking in several subsequent publications. In Lotus Buds (1909) she quotes evidence from the Census Report for 1901 to expose the process of marriage to a temple god and the consequences of that union. She explains that it has been a custom in some districts for families without sons to dedicate a daughter to temple service:

The daughter selected is taken to a Temple and married there to a god, the marriage symbol [a tali] being put on her as in a real marriage. Henceforth she belongs to the god. [. . . To avoid the Penal Code (which forbids the marriage of children to gods) a

\footnotetext{
7 The devadasi system was made illegal in 1988. However, the question of whether devadasis were or were not prostitutes is a controversial one. For more on the complexities of the issue, see Amrit Srinivasan, 'Reform and Revival: The Devadasi and her Dance', in Economic and Political Weekly, 20 (1985), 1869-76; Saskia C. Kerenboom-Stoory, Nityasumangali; Devadasi Tradition in South India (Delhi: Motilal Benarsidas, 1987); and Leslie C. Orr, Donors, Devotees, and Daughters of God: Temple Women in Medieval Tamilnadu (New York: Oxford University Press, 2000).

- Amy Wilson-Carmichael, Things as They Are (London: Morgan and Scott, 1903), p. 221.

- Ibid., p. 222. She asked an Indian teacher about the girl. He recognized that her life was henceforth a passage 'down to hell', but explained that "The practice could not be defended; it was custom. That was all. "Our custom"' (ibid., p. 224).
} 
nominal bridegroom is sometimes brought for the wedding day to become the nominal husband. [...]

A Temple woman's son [. . . ] explains the very early marriage thus: 'If not married, they will not be considered worthy of honour. Before the children reach the age of ten they must be married. [...] They become the property of the Temple priests and worshippers who go to the Temple to chant the sacred songs.' ${ }^{10}$

Carmichael also includes a Hindu woman's account of how the children's ties with their families are broken:

Sometimes she is shut up in the back part of the house, and punished if she runs out into the street. The punishment is severe enough to frighten the child. Sometimes it is branding with a hot iron upon a place which does not show, as under the arm; sometimes nipping with the nail till the skin breaks; sometimes a whipping. ${ }^{11}$

Although this is a much more detailed description of the cruelties devadasis could experience, Carmichael still does not address the issue of child sexwhat it means to become 'property of the Temple priests'-explicitly. Her use of euphemism may have been in response to the opposition she had faced from other missionaries and colonialists who did not initially believe her claims. It may also have emanated from concerns about how to discuss sex-especially sexual practice which her Western readership would have identified as being deviant-as a respectable and pure-minded Christian woman. This was a problem which earlier female social reformers had experienced. While in Paris during December 1874, Josephine Butler (1828-1906) wrote an account of her stay for the radical MP James Stansfeld in which she referred to the problem of child prostitution in the city. As Jane Jordan explains:

[S] he had heard of certain houses where "these poor young slaves are [.. .] "farmed by the night", others by the hour, night and day', but was unable in the letter to tell him all that she had seen and heard. It was 'too painful to dwell upon'. This would become a familiar apology. The horrors she had heard of, or had actually witnessed, were too far removed from the experiences of her colleagues at home to be spoken of, certainly by a woman. ${ }^{12}$

It was not until the 1880 s that Butler revealed the full extent of her knowledge of the white slave trade, and started her campaign against the traffic and prostitution of girls and women in Europe.

It is notable that, when addressing a like-minded audience of Evangelical Christian women, Carmichael was able to write with particular confidence. In two short articles of 1906, published in the CEZMS's periodical India's Children and China's Daughters, ${ }^{13}$ she discusses the situation in a tone of indignation:

10 Amy Wilson-Carmichael, Lotus Buds (London: Morgan and Scott, 1909), pp. 258-59.

1 Ibid., p. 260.

12 Jane Jordan, Josephine Butler (London: Murray, 2001), p. 164.

13 Amy Wilson-Carmichael, "Lost Lambs": Miss Amy Wilson-Carmichael's Work in Southern 
[1]t is hardly more awful that a young girl should occasionally perish on the altar of a false god, with mistaken heroism, than that the purity of tens of thousands of girl-children, chosen with regard to their attractive qualities, should be sacrificed in the Temples of South India. ${ }^{14}$

Her ministry must have been supported by the CEZMS, as it sanctioned the publication of her pieces, and her tone has noticeably shifted from being uncertain about how best to discuss her work, to a powerful voice of righteous anger. Certainly, a decade after she started her work with temple children Carmichael was able to write with vindication that, although even long-serving missionaries had doubted the existence of devadasis in the early years of her work, 'Indian brethren' had subsequently helped expose the reality of the scores of secret marriages of young children to the gods in certain cities. ${ }^{15}$

A decade later, Katherine Mayo (1867-1940), an American social reformer who admired Carmichael's ministry, ${ }^{16}$ was much more open in providing evidence against the sexual exploitation of children. In her controversial Mother India she produced a shocking list compiled from medical evidence presented to the Indian Legislative Assembly in 1922 about the appalling consequences that could ensue from such early sexual misuse:

A.-Aged 9. Day after marriage. Left femur dislocated, pelvis crushed out of shape. Flesh hanging in shreds.

B.-Aged 10. Unable to stand, bleeding profusely, flesh much lacerated.

C. - Aged 9 . So completely ravished as to be almost beyond surgical repair. ${ }^{17}$

This disturbing record highlights the types of abuse and the potentially fatal consequences from which Carmichael was attempting to save temple children.

At the same time, Carmichael was aware of the political and 'racial' implications of 'white' Christians intervening to protect 'native' Hindu children. She asked: 'Does this sound intolerant and narrow, as if no good existed outside of our little pale?'18 She insisted that this was not her intention, but her story nevertheless raises a debate about the extent to which such crosscultural attempts by 'Occidentals' to protect 'Oriental' children may be interpreted as perpetuating colonialist ideas of Western moral-and, in the case of the missionary Carmichael, religious-superiority. Indeed, Katherine Mayo's work, which expressed the author's belief that India was not ready for selfgovernance, particularly with regard to gynocentric issues such as child mar-

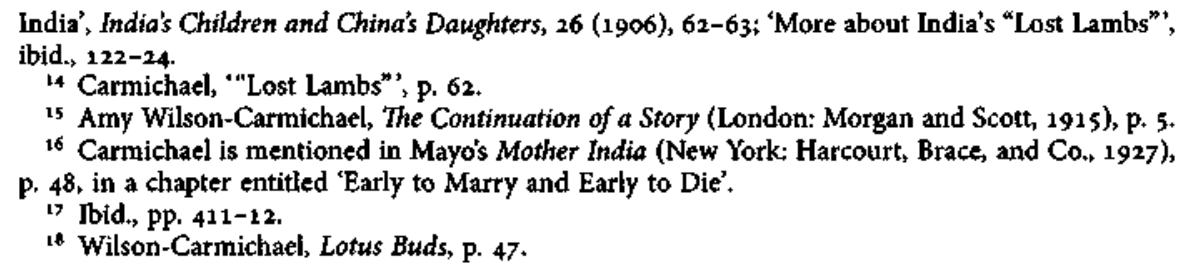


riage and young pregnancy, was challenged for exactly this reason. Her book roused anger among pro-independence groups; it was denounced as being untruthful by Mahatma Gandhi, and was burnt in India and New York. The objections mainly emanated from the fact that Mayo was an outsider; although her research was done at first hand (via interviews with officials and reviews of debates from the legislature), critics suggested that she could not understand the system because she was not part of the culture. It is easy to see that similar claims could be made against Carmichael's work of 'rescuing' children from Indian temples. Yet both of these women's endeavours made a lasting impact in India. Despite condemnation of Mayo, the minimum age for marriage was raised to fourteen for girls and eighteen for boys after the publication of her book. In the case of Carmichael, the endurance of her vision is perhaps best demonstrated, as Myrtle Hill has asserted, by the fact that 'the community survived both the ending of British rule in India and her own death in 1951. [...] [A]lthough the fellowship members are now all of Indian nationality, the work still continues today. ${ }^{19}$ Indeed, the eventual indigenization of the Fellowship is an indicator that its agenda was primarily concerned with the protection of vulnerable children, and did transcend 'racial' ideologies concerning 'white' supremacy.

\section{Dohnavur}

By 1901 Carmichael had moved her mission to a compound covering an area of about 170 acres in Dohnavur, a village about fifteen miles south of Tinnevelley. This became the permanent residence of her mission. Here, housing, schooling, and medical services were provided for the protection and nurturing of vulnerable children. Carmichael insisted that the Fellowship was a family and not an orphanage; she particularly wanted it to be as close as possible to a Tamil family. Within the compound walls, she tried to promote the growth of an indigenous Indian Christianity. Tamil was the first language, although English was also taught concurrently. She herself wore a sari almost from the beginning of her time in India, much to the disapproval of most of the missionary community. ${ }^{20}$ The Dohnavur children were not dressed in European clothes either; instead, they wore garments that were more in keeping with local customs. As Carmichael explained in one of her books about the Fellowship, while many Western-influenced organizations dressed Indian infant girls (who traditionally enjoyed the freedom of going

19 Myrtle Hill, 'Carmichael, Amy Beatrice (1867-1951)', in Oxford Dictionary of National Biography (Oxford University Press, online edn, January 20.08) <http:/www.oxforddnb.com/view/ article/59081> [accessed 6 November 2008].

30 This is perhaps illustrative of the Victortan fear of 'going native', which would be construed as the opposite of the 'civilizing' mission. 
naked) in 'print frocks, sometimes frilly and tucked, or very long print petticoats tied tightly round the waist with a tape', the Dohnavur children were dressed in

knickers, kept up by little straps over the shoulders and crossed at the back. It was not Indian, and we wanted to be Indian. But it was as inoffensive as we could attain unto. [...] At a later stage, another garment had to be [used]. The perfect Indian garment is a sari, but it is too complicated for very tiny girls, and so we put ours into cumasus, which are sleeveless, low-necked, and undecorated, and bridge the gulf between knickers and saries. $^{21}$

She clearly believed her work was progressive and not mainstream in aspiring to be both culturally sensitive and practical, and she promoted this approach to missionary work in her writings.

\section{Carmichael's Writings}

Carmichael's ministry extended to writing about her missionary work, methodology, and the theology which emerged out of her particular experiences. She started this practice early in her career: in 1895 she published a book entitled From Sunrise Land: Letters from Japan about her first fifteen months' experience in the East. While this volume attempts primarily to describe the mission field, it also provides information about Japanese culture and peoples which renders it a kind of travel or ethnographic writing; for instance, she explained to her British reading public that:

Their [the Japanese people's] courtesy is a marked characteristic. If one gets in your way for a moment, he exclaims that he is an honourable bother, (rather meaning that he has had the honour of being a bother to you,) and promptly removes himself. ${ }^{22}$

This is also often the case with her writings about India. Her earliest Indian pieces were published in the CEZMS's quarterly periodical India's Women and China's Daughters. ${ }^{23}$ As is suggested by the titles of her first two contributions'Letter from Miss Amy Wilson Carmichael, "Tinnevelly District", ;4 and "Tinvelley Village Mission: A Sketch from Paneivilei. By our "Keswick Missionary," Miss Amy Wilson Carmichael. 1897'25 - these were short descriptive works introducing the mission and vicinity she was serving in. Later, she used this publication to raise awareness of her work among vulnerable children, as has

21 Amy Carmichael, Tables in the Wilderness (London: SPCK, 1923), pp. 40-41.

${ }^{27}$ Amy Wilson-Carmichael, From Sunrise Land: Letters from Japan (London: Marshall Brothers, 1895), p. 18.

${ }_{23}$ This periodical ran from 1880 to 1939 . The title was initially India's Women, but this was changed to reflect the expansion of the Society's work in 1896.

24 India's Women and China's Daughters, 17 (1897), 255-58.

2s Ibid., 18 (1898), 276-77. 
been demonstrated above. ${ }^{26}$ However, as her particular ministry expanded and her work gradually separated from that of the CEZMS, ${ }^{27}$ she started to produce more detailed, lengthier works independent of the Society. These were mostly published in London by the Society for the Propagation of Christian Knowledge (SPCK) ${ }^{28}$ with distinctive cobalt blue cloth covers bearing a gold lotus-like motif on the bottom right corner.

A prolific writer, she published thirty-five books during the fifty-six years of her ministry in India. She wrote mostly about her practical mission experiences in her prose works. As indicated by the title of her earliest work to gain wide circulation-Things as They Are (1903) - she believed that most people were uninformed about the realities of mission work. This book, which sought to expound the real difficulties of missionary service in India, was considered too shocking and discouraging by some missionaries and members of the British Raj. In addition to its disturbing revelations about the devadasi system, and the plight of child brides and widows, it contained stories revealing how unresponsive and lacking in deference Indian people could be towards missionaries, thus challenging the colonial dynamics of power.

After this, she published several works relating specifically to the temple children. Beginning of a Story: To the Temple Children's Friends [An Account of Mission Work Among Temple Children in India] (1908) and Continuation of a Story (1915) were pamphlets intended for wide circulation to raise awareness about the plight of the devadasis. Lotus Buds: Tales of Child Life in India $(1909)^{29}$ was a lengthy tome which narrated the stories of several children saved from poverty and abuse, and sought to provide more facts about the devadasi system. All of these texts are frequently written in the compelling style of a storyteller-Carmichael seems to do this consciously, as the titles themselves suggest. For instance, Things as They Are opens with the following passage:

Three friends sat Native fashion on the floor of an Indian verandah. Two of the three had come out to India for a few months to see the fight as it is. As they saw it. They now proposed that the third should gather some letters written from the hot heart of things, and make them into a book, to the intent that others should see exactly what they had seen. The third was not sure. The world had many books. Does it want another, and especially another of the kind this one would be? (p. z)

Almost in the manner of a children's story, Carmichael commences by provid-

${ }^{26}$ Her books were later reviewed in this periodical; Lotus Buds (1909) is reviewed in no. 30 (1910), p. 25.

${ }^{27}$ All formal ties with the CEZMS were severed in 1925, and the Dohnavur Fellowship was established in 1926 .

${ }^{18}$ Now known as the Society for Promoting Christian Knowledge, this is the oldest Anglican mission organization.

29 There was a second edition in 1923, published by SPCK. 
ing the setting. She then alternates between long and short sentences, and also asks a question. The effect created is that of drama and anticipation.

Later works, such as Tables in the Wilderness (1923) and Meal in a Barrel (1929), describe life in and publicize the work of the Fellowship, and are beautifully illustrated with sepia photographs of Dohnavur. These books are full of poignant and inspirational stories about members of the community, especially the children. A few books concentrate on the stories of remarkable individuals among the Indian population. Ponnammal: Her Story (1918) is a memorial about an Indian widow convert who joined Carmichael's ministry in 1897 and dedicated the rest of her life to Christian service, especially the care of the Dohnavur babies and infants. Raj, Brigand Chief: The True Story of an Indian Robin Hood Driven by Persecution to Dacoity (1926), written in the form of an Evangelical Christian novel, is an exhilarating retelling-so exciting that it was later made into a film-of Carmichael's conversion of a fugitive bandit, which also exposed the corruption of some policemen in southern India. ${ }^{30}$ Ragland, Pioneer (1922) is a biography of the Church Missionary Society's Thomas Gajetan Ragland (1815-1858), a famous nineteenth-century itinerant evangelist who worked in southern India. ${ }^{31}$

On 24 October 1931 Carmichael fell into a pit which had been dug in the Dohnavur estate. The accident left her an invalid for the rest of her life and she rarely left her room. Under these conditions, Carmichael channelled her energies into her writing. Gold Cord: The Study of a Fellowship (1932), another illustrated volume which includes a map of the compound printed on the endpapers, is a full history of the development of her organization. As a result of her physical confinement, her later publications are often contemplative devotional works of inner faith; however, her surroundings continued to inspire her, and these works often meditate on natural images and cycles of southern India, such as Gold by Moonlight (1935) and Windows [On the Dohnavur Fellowship] (1937). As Eric Sharpe observes, 'Probably no active missionary has ever published so much; possibly no missionary has ever written better, in point of style. ${ }^{32}$ Indeed, her writings are often compelling narratives which attempt to convey both the charm of the Dohnavur children and the dark threats she perceived as existing in the outside world:

As I write, the happy sound of children's voices and laughter draws me to look out. I see green forest, nothing but forest, except just in front of the house, where the grey rocks break through. And on one of these rocks with this green for background I see

\footnotetext{
${ }^{20}$ Eliza F. Kent, Converting Women: Gender and Protestant Christianity in Colonial South India (Oxford: Oxford University Press, 2004), pp. 111-12, writes in some detail about the 'sexual undertones' of this narrative.

31' In the second edition of 1938, this book was renamed Ragland: Spiritual Pioneer.

32 Eric J. Sharpe, 'The Legacy of Amy Carmichael', International Bulletin of Missionary Research, 20 (1996), 121-25 (p. 121).
} 
two little blue figures [two infants dressed in blue knickers] standing. They scrambled up a moment ago, like the birds, very happy in sunshine after a wet week. One of them, a hardy, plucky child stands on tiptoe pointing to the wonders of the valley below to her little companion. I can hear the eager chatter. I look at her, and think of the dark place as the pit, hundreds of miles from Dohnavur, the place which all but possessed her. Many a darling child has been sucked into that vortex. ${ }^{33}$

\section{Scholarship on Carmichael}

Despite Carmichael's considerable corpus of writings, little scholarship has been undertaken on her works. Her writings have always been best known in Evangelical circles. ${ }^{34}$ After her death, an official Dohnavur biography was written by Frank Houghton, but this concentrated on the outward life and did not assess her writings in depth. ${ }^{35}$ Indeed, most books on Carmichael have been biographies. The fullest and most critical is Elisabeth Elliot ${ }^{2},{ }^{36}$ which offers a detailed history of Carmichael and her work. Elliot is keen to celebrate Carmichael's achievement, but does not shrink from rounding out the depiction of her subject by alluding to her flaws and failings; for example, she describes the missionary's jealousy at the arrival of a missionary family who "made a hit with the girls', 37 and her Victorian sexual prudery; the older Dohanvur girls were not allowed to play sports probably owing to the possibility that an ankle might be glimpsed'. ${ }^{38}$ In contrast, most other biographers have been hagiographical, jealously guarding Carmichael's image as a maverick heroine and saint of the modern Church. ${ }^{39}$ Although these often amount to little more than inspirational adventure stories for Evangelical readers, they repeatedly recognize and affirm the importance of Carmichael's life experiences in the development of her distinct theology as expressed in her writings.

Of the scholarly work done on Carmichael, a focus has been on the retelling of her inspiring story and pioneering contribution to missiology, as in the articles by Eric Sharpe and D. Arthur Jeyakumar. ${ }^{4 \circ}$ Ruth $A$. Tucker considers

3) Amy Carmichael, Windows (London: SPCK, 1937), p. 88.

34 For instance, her verse is quoted in Joy Guinness's biography of another woman missionary, Mrs. Howard Taylor: Her Web of Time (London: China Inland Mission, 1949).

35 Frank Houghton, Amy Carmichael of Dohnavur: The Story of a Lover and her Beloved (London; SPCK, 1954).

36 A Chance to Die: The Life and Legacy of Amy Carmichael (Grand Rapids, MI: Revell, 1987); issued in the UK as Amy Carmichael: Her Life and Legacy (Eastboutne: MARC, 1988).

37 UK edn, p. 268.

38 Ibid., p. 297 .

39 These include Nancy E. Robbins, God's Madcap: The Story of Amy Carmichael (London: Lutterworth, 1962), Elizabeth R. Skoglund, Amma: The Life and Words of Amy Carmichael (Grand Rapids, MI: Baker, 1994), and Janet Benge and Geoff Benge, Amy Carmichael: Rescuer of Precious Gems (Seattle, WA: YWAM, 1998).

to Sharpe, 'The Legacy of Amy Carmichael'; D. Arthur Jeyakumar, 'Amy Carmichael of Dohnavur 1867-1951', Indian Church History Review, 36 (2002), 5-11. 
three missionaries who served in southern India, but concentrates on the reception history of Amy Carmichael's reputation. ${ }^{41}$ She builds on James William McClendon Jr's study, which challenges readers to utilize biography as a theological tool, and thus argues the need for accurate and rigorous missionary biographies. ${ }^{42}$

An article by Daniel Jeyaraj introduces and examines Carmichael's ministry by considering three of her books-Things as They Are, Lotus Buds, and God Cord ${ }^{43}$-and providing some historical context about the independence movements, caste system, and devadasis in India. Kent's study delivers a more critical analysis of Carmichael's work with the Dohnavur Fellowship. For instance, she suggests that Carmichael was not reconciled to the signs of 'pagan' spiritualities evident everywhere in India, and that this meant she was able to create her 'vision for an indigenized evangelical Indian Christianity' only behind the thick red walls of the Dohnavur compound, which led to failures in her project (such as the fact that the Dohnavur children learnt Tamil with an unusual accent which was difficult for outsiders to comprehend). ${ }^{44}$

\section{Missionary Poetics}

In addition to her prose works, Carmichael wrote a substantial body of Christian verse which articulated the particular theology which she developed in response to her specific circumstances and needs. These were published during her lifetime in Made in the Pans (1917), a volume of war poetry; Dohnavur Songs (1920), hymns written for the children of the Fellowship; Toward Jerusalem (1936), a volume of devotional poetry and hymns; and Pools and the Valley of Vision (1938), a mystical work about Indian nature. ${ }^{45}$ These poetical works, which effectively display Carmichael's hope for the development of an authentic Indian Christianity that responds to the experiences and needs of Indians, have not been assessed by literary scholars.

One of the prime means by which Carmichael sought to develop an indigenous Indian theology was to expound on God's nature through commentary on the Indian landscape, its flora and fauna. ${ }^{46}$ This strategy is perhaps most clear in Pools, a poem divided into twelve short chapters, which was written

41 Tucker, 'Biography as Missiology'.

${ }^{2}$ Biography as Theology: How Life Stories Can Remake Today's Theology (Nashville: Abingdon Press, 1974)

${ }^{43}$ Daniel Jeyaraj, "Amy Carmichael: The Child-Rescuing "Amma", American Baptist Quarterly, 24 (2005), 220-41.

4 Kent, Converting Women, p. 108.

45 The collected poems have since been published in a single volume entitled Mountain Breezes: The Collected Poems of Amy Carmichael, with an introduction by Elisabeth Elliot (Fort Washington, PA: Christian Literature Crusade, 1999).

46 Elliot, Amy Carmichael, p. 214. 
some years (the exact date is unspecified) before its publication in 1938. In a note to the poem, Carmichael explains the inspiration for the work:

In Southern India the rivers which flow from the mountains and the water plains depend on the north-east and south-west monsoons. Often just before the first burst of the monsoon and again after it has spent its force, various rhythms and changeful notes in the water may be heard far down in the river bed.

What causes such changefulness? This is the story of a search for the answer to that question. ${ }^{47}$

Pools is a Christian poem which speaks imaginatively about the nature and climate of Southern India in order to preach about God's abiding presence and power in that part of the world. Carmichael is utilizing the idea of correspondences between the natural world and the heavens, as articulated in the Psalms, ${ }^{48}$ to express her opinion that the Indian elements also declare the glory of the Lord:

2. $[\ldots]$

\section{[...] I sat one day}

In showery sunshine by a mountain stream. And presently I was aware of tunes

That came and went like intermittent chimes, Or like the silver bells of fairy-land.

[...]

Intent, absorbed, I bent me low and listened While spray of water-music rained on me And drenched me in delight. The forest trees Bent down with me, each several living leaf A listening ear. I thought the mountains listened, They stood so still. [...]

3. [...]

\section{A Voice declared:}

$$
\text { [ . . ] 'What lies beyond?' I cried. }
$$

Glory and honour are in His Presence; Strength and gladness are in His Place, Worship the Lord in the beauty of holiness, Worship before Him and veil thy face.49

Cover thy feet and cover thy face

47 [Amy Carmichael], Pools and the Valley of Vision (London: SPCK, 1938), p. 8.

48 See e.g. Ps. 19. 1-4: 'The heavens declare the glory of God; and the firmament sheweth his handywork. Day unto day uttereth speech, and night unto night sheweth knowledge. There is no speech nor language, where their voice is not heard. Their line is gone out through all the earth, and their words to the end of the world.'

49 The idea of veiling one's face may be interpreted as a way of appropriating non-Christian 'Other' markers as part of a Christian mode of worship. 
Like to the winged seraphim. He is thy God and worship thou Him.

$$
\text { (pp. 12-14) }
$$

As the poem develops, Carmichael accentuates the Indian setting; for instance, halfway through the work the country is named directly: "It was the breathless hour of India's thirst' (p. 16). This is followed by a description of the arid Asian landscape before the monsoon:

I saw them open; crumpled levels flattened, colours mixed, hot red and tawny browns, In fierce and general furnace.

In a later chapter, a description is given of 'the Indian thrush' as 'an evangelist' surrounded by 'Believing birds' (p. 18). Such segments serve to suggest that an inherent Indian Christianity already exists in the land.

The implications and meanings of Carmichael's Christianizing of Indian nature in her verse require some further consideration. Kent has posited that Carmichael may have been panicked by her personal responses to the beauty of Indian nature because she found herself "unconsciously acting in a "Hindu" manner'. ${ }^{50}$ She retells a story about Carmichael walking in the hills of the Western Ghats and feeling inspired with thoughts of God's glory until she came upon a Hindu tree-shrine. Incensed by the 'pagan' stones, she destroyed the shrine by knocking them down. Kent writes:

It is possible that Carmichael was moved by the same spiritual thoughts as were the Indians who erected the shrine: admiration for the natural beauty of the surroundings and the sublime workings of the divine. Yet, instead of recognizing her own responses might be similar to those of Hindus, she vehemently disavowed such a possibility. The fear of being overwhelmed, of being colonized herself by India drove Carmichael to found a fully self-contained institution where she could experiment on her own terms with what seemed to her to be the dangerous, but powerfully attractive, possibilities of indigenization. (Converting Women, pp. 105-06)

It may be questioned whether Pools is an example of such self-contained indigenization, or rather demonstrates that Carmichael did manage to reconcile the spiritual responses she felt in reaction to Indian nature and landscape. While Carmichael does not permit 'native' elements such as Hindu shrines to penetrate her Indian landscape in Pools, thereby avoiding a point of Christian crisis, this almost pantheistic poem, which gives the elements spiritual personalities enabling them to listen for and respond to the divine, was published for the Christian world to read widely. Even if she was at times frightened, consciously or not, of reacting 'in a "Hindu" manner', I would suggest that, in her verse

so Converting Women, p. 105. 
writing at least, she channelled her ability to be moved to contemplation by indigenous nature for her own evangelistic purposes.

Other poetical works by Carmichael also attempt to speak about God's relationship with Indian people using indigenous images. 'Bladderwort' was first published in Dohnavur Songs: Songs of the Children of Dohnavur (1920), a slim volume of fifty hymns. It is included in the section entitled 'Little Children's Songs'. While species of bladderwort can be found on every continent except Antarctica, this hymn indicates that it grew inside the Dohnavur compound within sight of the Fellowship's children. Here, Carmichael initially seems to liken a feisty child dressed in blue knickers to a hardy bladderwort. Then in the second verse she anthropomorphizes the bladderwort by praising it as if it were a brave little child:

1. Brave blue bladderwort! Down the water dashes, In a swift tumultuous leap Over you he flashes; With a mighty, mighty roar On the black rock flashes.

2. Brave blue bladderwort! Well you know your river; Could a thousand thousand falls Make your blue bells quiver? You are not a coward flower. So why should you quiver?

3. King of water-floods. Maker of the wild-flowers, Raging forces own Thee Lord, Thine are all the world-powers. What can hurt what Thou dost guard, Little children or wild-flowers?si

She suggests that, despite growing amidst danger, the bladderwort is not frightened because it trusts in God's ability to protect. Her message is that the God who guards wild flowers is likewise in a position to be able to keep little children-'human flowers', as she sometimes referred to them-from harm. Carmichael does not specify what danger lurks for them; the third verse, which addresses God as the 'King of water-floods' and 'Raging forces', could imply that he protects from the perils of drowning. However, in the context of the work of the Dohnavur Fellowship, much darker meanings are also encompassed: the harm that adults can inflict on children through neglect, abandonment, and abuse lurks beneath the innocent surface of this children's song. Carmichael

"[ [Amy Wilson-Carmichael], Dohnavur Songs: Songs of the Children of Dohnavur (Madras: SPCK, 1920), p. 38. 
has written a hymn for her Indian children which emerges out of their circumstances and addresses their theological needs.

These Dohnavur songs were written because Carmichael felt that established English hymns were not culturally appropriate for her Indian children. As she explained in Though the Mountain Shakes (1943), a book about life at Dohnavur:

We dreaded [...] the insincere and what John Wesley called the namby-pambical. [...] There were many pleasant songs to be found, though most were a little too English; and there were some perfect hymns for children; but it is curious how questioning the mind becomes when it is thinking of the Indian child carefully considering the meaning of every word: 'Pity my simplicity, what did that mean? ${ }^{\text {?2 }}$

She wanted the gospel to meet the circumstances of her children. The answer seemed to be for the members of the Fellowship to write their own hymns: 'as the simplest way to help these children who at that time had no teachers, we began to make rhymes and songs for them, little things that they could sing truthfully'. ${ }^{53}$ Music and singing were extremely important components of the Dohnavur community under Carmichael's leadership:

One of the greatest pleasures we can give our children is to gather them for an hour's singing. We are glad and grateful that it is so. We have none of the diversions or excitements of cities, but we have books, mountains, forest, sea, music, song. And all that is pöthum' said one, after hearing of other and different delights, and pōthum means 'enough.' (Ibid., p. 193)

This extract conveys her desire for Dohnavur to be a place where children might learn to appreciate the simple pleasures of the natural world over busy man-made distractions, and where life, become holy, is set apart from the crowded streets of the cities.

'The Angels and the Tiger' is another hymn which affirms God's heavenly care of the Dohnavur children using an Indian image:

1. I think the careful angels walk Where little children be.

One night a tiger came to stalk His game quite near our nursery.

2. On our verandah, as we slept In the warm open air

We dreamt good dreams; they kindly kept Their watch around us everywhere.

3. And in the morning, when we saw And counted eagerly

52 Amy Carmichael, Though the Mountains Shake (Madras: Diocesan Press, 1943), pp. 191-92.

53 Ibid. p. 192. The music came largely from the missionaries of the Fellowship. 
The marks made by each great big paw A stone's-throw from our nursery,

4. We wondered what the angels said To make him go away,

Perhaps they patted his soft head And whispered, 'Tiger, you're astray.

5. See, we will show you by our light The way that you should go.'

And gently led him through the nightI wonder was it really so?

[But the tiger was shot the next day by some one who did not know about the angel.] ${ }^{54}$

The tiger is, of course, the indigenous element of the hymn. It acts as a signifier of danger for the Dohnavur children; however, Carmichael teaches again that they need not be afraid, because she asserts that angels constantly watch over them even when they are defenceless, asleep at night on an open verandah. This idea about powerful guardian angels, through whom even a wild tiger is rendered as tame and harmless as a domestic pet ('Perhaps they patted his soft head'), offers reassurance and comfort, possibly also delight at the prospect that the Old Testament prophecy of the 'wolf' dwelling with the 'lamb' (Isaiah 11. 6) has been wondrously fulfilled.

At the same time the short, seemingly unimportant bracketed comment points to a serious 'grown-up' discussion about how to deal with 'beasts' and 'monsters'. The angels have started the reformation or 'conversion' of the 'tiger', but then he is destroyed by someone who does not understand the spiritual processes that have occurred. The tiger is described as being 'astray', pointing to the possibility of returning to the correct path-undergoing Christian transformation and receiving forgiveness. Carmichael's hymn thus intimates that even deadly 'beasts' have the potential for guidance, correction, and the cultivation of goodness within. However, the tiger is then punished by someone who does not understand or believe that such redemption is possible, thereby ending the story with something of an anticlimax.

Carmichael's poetical preoccupation with the protection of children was no doubt linked to her work with the Dohnavur Fellowship. This is made clear in a section of 'Even There', a long poem published in her first book of verse Made in the Pans:

I know it well;

For once a scale was given to me by which All anguish may be measured. On that day I stood fast bound, whilst hurrying down the road Fled a young life, and after it in haste

s4 [Wilson-Carmichael], Donhavur Songs, pp. 35-36. 


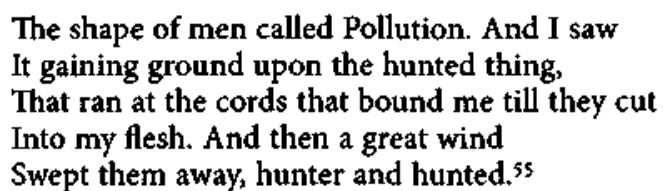

This work seems to be alluding to the time when Carmichael first learnt about child devadasis, as discussed in Things as They Are (pp. 217-18). She there describes the sense of feeling 'bound' and cut deep by her inability to help when she first witnessed child suffering at adult hands. Her personal view on child abuse, that it is the gravest of crimes, is indicated in the poem by the lines 'a scale was given to me by which / All anguish may be measured'. The 'young life' is an innocent creature hunted by ravenous, degenerate, fallen adults'Pollution'-aided by an ominous 'great wind', which seems to be a metonym for the invisible, malevolent forces of the world.

Carmichael sought to protect children from such dangers not only through practical action, but also through the dissemination of her writings; a central concern in Made in the Pans is to impart knowledge about the sexual exploitation of some groups of children in India. The situation is described in terms of a battle of good against evil; indeed, the collection, which unusually in Carmichael's poetic ouvre contains commentary on European politics-a number of poems are written in response to the brokenness of the First World War-is self-consciously a volume of war poetry. The subjects of her war poems are conventional: 'This Great Obedience' is about a wounded lieutenant who was left behind to die while urging his comrades to continue with their duty; 'Spray' is inspired by a letter written by a father after hearing of the death of his only son; and 'The Medical Way' is about a medic shot through the head while tending to the wounded on the front. These poems are scattered in the volume amid works relating to Carmichael's life in India, unaffected in real terms by the battles raging on the Western Front. By producing this mixed volume of poetry, Carmichael attempts to demonstrate a common human condition shared between the British and Indians. Through application of the biblical idea of spiritual warfare, the experiences of two distant nations are made comparable.

'A War-Chant: Before a fight in the law-courts for the honour of a Child' uses martial language to speak about the defence of vulnerable children. The poem talks of 'The noise of whips' and 'The thunder of Captains', and asserts that 'The Lord Thy God is a Man of War'.56 Without the parenthetical subtitle, it reads as a standard Christian poem which urges the anguished soul to have faith in a trustworthy God. However, Carmichael builds on the conventional

ss Amy Wilson-Carmichael, Made in the Pans (London: Oliphants, 1917), p. 32.

56 Wilson-Carmichael, Made in the Pans, p. 28. 
idea of God as a fortress (derived from the Psalms) against harm, conflict, and stress. She asserts that he is

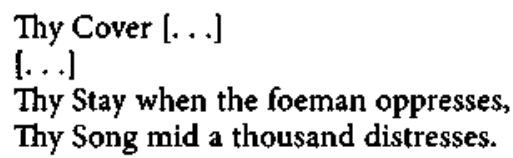

$$
\text { (p. 29) }
$$

Mental torment and spiritual sorrow are interpreted as being comparable to the near-fatal wounds sustained in bellicose attacks:

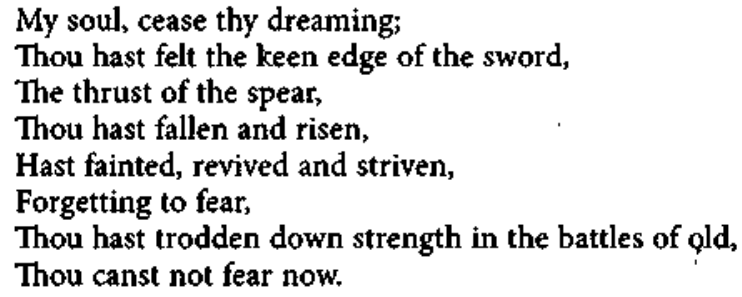

(p. 29)

Much of the language, its vocabulary and imagery, is borrowed from the Psalms of David, whose author likewise sought heavenly protection in times of war and mortal danger, and this poem asks for the same help for 'the honour of a Child' (p. 28). Euphemism is being employed again; however, the informed reader who knows about Carmichael's work will understand that the child alluded to is likely to be Indian, and that the 'honour' being challenged is probably sexual.

Another work which seeks to counter the threat of dark spiritual powers against children is 'Our Children', the last work in Dohnavur Songs. ${ }^{57}$ This frightening hymn pleads for heavenly defence against the snares of the world:

1. Father, hear us, we are praying, Hear the words our hearts are saying, We are praying for our children.

2. Keep them from the powers of evil, From the secret, hidden peril, Father, hear us for our children.

3. From the whirlpool that would suck them, From the treacherous quicksand, pluck them. Father, hear us for our children.

4. From the worldling's hollow gladness, From the sting of faithless sadness, Father, Father, keep our children.

37 In later printings this poem is revised and re-entitled 'For Our Children'. 
5. Through life's troubled waters steer them, Through life's bitter battle cheer them, Father, Father, be Thou near them.

6. Read the language of our longing, Read the wordless pleadings thronging, Holy Father, for our children. For the children Thou hast given.

7. And wherever they may bide, Lead them Home at eventide.

(pp. 60-61)

As a song, it functions like a prophylactic lullaby-indeed, the work ends with 'eventide' - which aims to ward off danger. The 'Our Children' of the title are most obviously the children of the Dohnavur Fellowship, but the phrase may also be applied in gradually widening circles to those of India, Britain, and, ultimately, the whole world. Although the peril is 'secret' and 'hidden', and not actually named, in terms of the work of the Dohnavur Fellowship, it again comprises the sexual misuse of children, including child brides and devadasis. Implicitly, the shocking subject of paedophilia is included in 'the whirlpool that would suck them'. Here, euphemism is perhaps also being employed because it would be possible for 'little children' to hear or read this Dohnavur song without being exposed to all of its possible meanings. The quick, steady pace of the song, with its many repeated words and phrases, gives it the feel of an incantation; it is as if Carmichael is invoking a protective spell to bind her children to safety.

She may have been influenced by Cecil Frances Alexander's equally prophylactic 'St Patrick's Breastplate', which asks for 'His heavenly host to be my guard':

7. Against all Satan's spells and wiles, Against false words of heresy, Against the knowledge that defiles, Against the heart's idolatry, Against the wizard's evil craft, Against the death-wound and the burning,

The choking wave, the poison'd shaft, Protect me, Christ, till Thy returning. ${ }^{58}$

Certainly, Carmichael's hymn replicates the anaphora of 'St Patrick's Breastplate', which communicates a sense of fearful urgency, and, apart from the final rhyme on 'burning'/returning', follows the same tetrameter pattern. With her Northern Irish roots, it is possible that Carmichael applied the Celtic tradition

58 'St Patrick's Breastplate', in Cecil Frances Alexander, Poems, ed. by William Alexander (London: Macmillan, 1897), p. 61. 
of protection from harm as demonstrated in Alexander's hymn to the circumstances of her Indian Dohnavur children. In this case, 'Our Children' is a work of cultural hybridity, which liturgically attests to God's power to care for Indian children in the language of a Celitic prophylactic prayer.

It seems unlikely that 'Our Children' was written for children to sing; instead, it is a prayer for adults to make supplication to God for his righteous deliverance. A prefatory note to Dohnavur Songs explains, "because they were asked for by their friends a few of a more grown-up nature have been added',59 and it is likely that 'Our Children' is one of these works..$^{60}$ (This hymn is the only one of the fifty Dohnavur Songs which is not attributed to a particular child in the contents list; for instance, the first song 'Hush' is called 'Ruchipu's Song', while the penultimate one 'Influence' is called 'Tara's Song. ${ }^{61}$ ) Interestingly, 'Our Children' is written in the same metre as the Dies Irae ('Day of Wrath'); the first five verses of Carmichael's hymn follow the same pattern of three-line verses of trochaic tetrameters and differ only in the rhyme-scheme. Her final two verses also conform to the prosody of the final two verses of the medieval hymn:

\author{
18. Lacrimosa dies illa, \\ Qua resurget ex favilla \\ Judicandus homo reus: \\ Huic ergo parce, Deus. \\ 19. Pie Jesu Domine, \\ dona eis requiem. ${ }^{62}$
}

Carmichael may have been alluding to this work in order to convey the anger of God at iniquitous human actions, anticipate his future dispensation of divine justice, and alarm the perpetrators of heinous crimes to repentance and reform.

Adult exploitation of children is alluded to again by Carmichael in the first verse of 'Come, Lord Jesus', which is included in Toward Jerusalem (1936), a collection of meditative devotional poems for adult readers:

1. Because of little children soiled, And disinherited, despoiled,

2. Because of hurt things, feathered, furred, Tormented beast, imprisoned bird,

s9 [Wilson-Carmichael], Dohnavur Songs, p. 1.

${ }^{6}$ One modern instance of the hymn being used by an adult is recorded in Lewis and Betty Drummond's The Spiritual Woman: Ten Principles of Spirituality and the Women Who Lived Them (Grand Rapids, MI: Druegel, 1999). Here, Carmichael's hymn is said to have been used by the Liverpudlian Evangelist Jill Briscoe as a prayer over her children, and is quoted in full on page 27.

6) Ibid., pp. 4-5.

6z Quoted from the Graduale Romano-Seraphicum Ordinis Fratrum Minorum (Paris: Typis Societatis S. Joannis Evangelistae, Desclee \& Socii, 1932), p. 100. 
3. Because of many-folded grief, Beyond redress, beyond belief,

4. Because the word is true that saith The whole world creation travaileth-

5. Of all our prayer this is the sum: O come, Lord Jesus, come. ${ }^{63}$

Again, Carmichael is evasive about what specific issues are being addressed: the idea that children are 'soiled', 'disinherited', and 'despoiled' could apply to children who are neglected, poverty-stricken, and/or abandoned, but can also relate, again, to those who have experienced the more disturbing offence of sexual abuse. Carmichael's elusiveness is effective in transmitting the sense of a shadowy, sinister, evil power which has to be fought.

Carmichael's repeated affixing of the adjective 'little' to 'children' in her hymns owes a debt to Victorian hymnody. For instance, Cecil Frances Alexander's Hymns for Little Children (1848), which includes 'All Things Bright and Beautiful', 'Once in Royal David's City', and 'There is a Green:Hill Far Away', is filled with 'little, weak and helpless ${ }^{34}$ and 'little modest' ${ }^{\prime 65}$ children. As with the Victorians, Carmichael's use of the word 'little' stresses their vulnerability, their ability to be easily lost. However, whereas it is likely that the nineteenth-century readers of Alexander's hymns would have linked the possibility of child loss primarily with death, Carmichael's 'little [Dohnavur] children' are understood by her readers to be in danger of becoming lost in different ways. While they too may fall prey to sickness and die, their minds and/or bodies may also be injured by adults who misuse their greater power and strength. Thus, Carmichael extends the idea of how children may be 'lost' into very uncomfortable territory, far beyond the relatively safe areas examined by Alexander. This is the unusual and significant uniqueness of Carmichael's verse, particularly within the corpus of English hymnody. ${ }^{66}$

Although her writings protested against the abuses and wrongs that she perceived in India, Carmichael's missionary literature was inscribed with the belief that the Christian God's incarnate love would ultimately bring an end to all injustice in the world. In Windows she meditated on natural phenomena to assert that, even in an imperfect world full of brokenness, startling beauty could still be found. She interpreted such sights as symbols of God's grace, and a foretaste of how he would restore the world to wholeness and health:

63 Amy Carmichael, Toward Jerusalem (London: SPCK, 1936), p. 108.

64 All Things Bright and Beautiful', in Hymns for Little Children (London: Joseph Masters, 1848), p. 31 .

os 'I Love the Little Snowdrop Flower', ibid., p. 52.

of I have not been able to find any comparable hymns in English. 
One day our Forest men brought down a $\log$ of rotten wood. It was [. . .] covered with [. . . ] a mass of fungi, like little arum lilies [. . ]. From many a place of pain to-day beautiful things are growing like this lily-fungus on the log. (Windows, p. 35)

Perhaps like the log of rotten wood, Carmichael's writings demonstrate how missionary literature, hitherto largely ignored by scholars, can be an intriguing and fertile site for literary enquiry. The conditions of missionary work, the encounter of different cultures and religions combined with a powerful social agenda, and an attempt to produce a new way of writing about the divine to express an authentic indigenous theology, enabled Carmichael to produce a challenging, brave, and visionary body of English literature. Her missionary writings suggest that arresting scenes may indeed be discovered in unexpected places.

NotTingham Trent UNIVERSITY

NANCY JiWON Cho 